\title{
微小発破の生体応用に関する研究
}

第 2 報 尿路結石の組成と強度

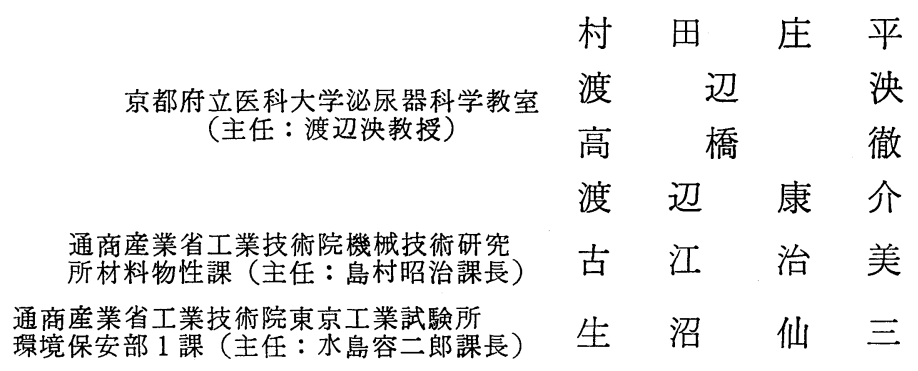

\section{STUDIES ON THE APPLICATION OF MICROEXPLOSION TO MEDICINE AND BIOLOGY}

II. Construction and Strength of Urinary Calculi

\begin{abstract}
Shouhei Murata, Hiroki Watanabe, Tohru Takahashi and Kousuke Watanabe
\end{abstract}
Department of Urology, Kyoto Prefectural University of Medicine

(Director: Prof. H. Watanabe)

Harumi Furue

Mechanical Engineering Laboratory, MITI

(Director: Dr. S. Shimamura)

Senzo Oinuma

National Chemical Laboratory for Industry, MITI

(Director: Dr. Y. Mizushima)

As one of the fundamental researches for the development of microexplosion lithotripsy, chemical component, density, hardness, compressive strength, tensile strength and the modulus of elasticity were measured on 66 dry urinary calculi. The results are as follows:

1) Chemical component was not so different from that of former reports.

2) Density was from $0.97 \mathrm{~g} / \mathrm{ml}$ to $1.75 \mathrm{~g} / \mathrm{ml}$.

3) Hardness was from $12.5 \mathrm{HRF}$ to $102.5 \mathrm{HRF}$.

4) Compressive strength was from $19.0 \mathrm{~kg} / \mathrm{cm}^{2}$ to $176.0 \mathrm{~kg} / \mathrm{cm}^{2}$.

5) Tensile strength was from $0.8 \mathrm{~kg} / \mathrm{cm}^{2}$ to $34.3 \mathrm{~kg} / \mathrm{cm}^{2}$.

6) A direct proportion was observed between the compressive and the tensile strength of calculi.

7) The modulus of elastisity was $5.4 \times 10^{8}$ dyne $/ \mathrm{cm}^{2}$ to $88.0 \times 10^{8}$ dyne $/ \mathrm{cm}^{2}$.

8) Almost no correlation was observed between the strength of calculi and their chemical component. Laminated calculi, however, were weaker than non-laminated one in most cases.

9) Urinary calculi could be classified into two groups according to their strength at the border of $65 \mathrm{~kg} / \mathrm{cm}^{2}$ in compressive strength and of $15 \mathrm{~kg} / \mathrm{cm}^{2}$ in tensile strength by dry sample. Approximately $80-90 \%$ of all calculi might belong to the "low strength calculus" group of which strength was under the borderline and the remaining $10-20 \%$ might belong to the "high strength calculus" group of which strength was over the borderline. 
10) From these results obtained by dry samples, it became evident that two kinds of calculus model should be prepared for the experiment of lithotripsy: the "low strength calculus model" of which strength was approximately $65 \mathrm{~kg} / \mathrm{cm}^{2}$ in compressive and $15 \mathrm{~kg} / \mathrm{cm}^{2}$ in tensile and the "high strength calculus model" of which strength was approximately $180 \mathrm{~kg} / \mathrm{cm}^{2}$ in compressive and $35 \mathrm{~kg} / \mathrm{cm}^{2}$ in tensile.

\section{緒 言}

前報》飞拈いて述べたよらに，微小発破の医学領域へ の応用として，最初に考兄られる対象は，尿路結石の破 砕である。この計画にあたり，発破の生体に拉よぼす影 響や爆薬量などを知るために，一定の強度の結石モデル を作製する必要があり，そのための第 1 段階として，私 たちはまず破砕される側の結石の組成ならびそ強度を調 ベることとした．

\section{方 法}

\section{1）実験材料}

実験には, 京都府立医科大学泌尿器科学教室与よび沖 縄県立中部病院泌尿器科飞执いて, 截石手術によつて採 取された乾燥尿路結石計66個を使用した。截石を行つた 患者の状態や結石の存在部位などそついては，今回の実 験目的とはあまり関係がないので，とくに検討しなかつ た。

\section{2）結石の成分}

結石成分については, 工業技術院東京工業試験所平 塚分室に执いて, 赤外線分光分析とX線回析による分析 を行つた. 赤外線分光光度計は JASCO MODEL IRSInfrared Spectrophotometer を使用し，KBr 錠剤法で行 い, X線回析装置は理学電気機械 KK の Diffraction Apparatus Model D-3F を用いた。

3）結石の密度

結石の密度は，同じく工業技術院東京工業試験所平塚 分室に䏡いて測定した，試料を立方体に研磨し，その三 辺の長さと質量を計測し, 密度を算定した。

4）結石の硬度

結石の硬度は, 工業技術院機械技術研究所材料物性課 飞执いて測定した. 試料を合成樹脂中に包埋し，砥石に て研磨して結石の中心部を通る割面を出し，その硬度を Rockwell 硬度計にて, 試験荷重 $60 \mathrm{~kg}, F$ 目盛にて測定 した。単位は $F$ 目盛による Rockwell 単位 $\mathrm{H}_{\mathrm{R}} \mathrm{F}$ にて示 した。

5）結石の圧縮強度, 引張り強度ならびに弾性率

これらの測定は, 同じく工業技術院機械技術研究所材 料物性課に打いて行なつた。

a ）圧縮強度
試料を概略の立方体飞成形して，インストロンタイ プの万能材料試験機, 島津オートグラフ IS-20T 飞装 着し、ロードセル容量 $500 \mathrm{~kg}$, フルスケール $10 \mathrm{~kg}$ ま は $25 \mathrm{~kg}$, 負荷速度 $0.5 \mathrm{~mm} / \mathrm{min}$ に設定して, 試料を圧縮 し, 破断を生じた時の荷重と, 破断面の面積計測結果と から，試料の圧縮強度を算出した。

b) 引張り強度

試料を成形したのち，その両端にそれぞれ1本ずつの 鋼線を接着剤にて接着し，鋼線を同じ測定装置に固定す ることによつて試料を支持し，同じ測定条件で試料を引 張つた。ただし負荷速度は $1.0 \mathrm{~mm} / \mathrm{min}$ とした。同じく 破断を生じた時の荷重と, 破断面の面積計測結果とか ら，試料の引張り強度を算出した。

\section{c) 弾性率}

前述の試料圧縮過程に打ける, 弾性限界内での応力 一雪み曲線の勾配より, 試料の圧縮弾性率を算定した。

\section{1）結石の成分}

結石成分の分析は，尿路結石66個の試料について行つ た。これらに含まれた成分は，下記の 5 種類であつた，

(1) $\mathrm{Ca}(\mathrm{COO})_{2}$

(2) $\mathrm{Ca}_{3}\left(\mathrm{PO}_{4}\right)_{2}+\mathrm{Ca}(\mathrm{COO})_{2}$

(3) $\mathrm{Ca}_{3}\left(\mathrm{PO}_{4}\right)_{2}+\mathrm{MgNH}_{4} \mathrm{PO}_{4}$

(4) $\mathrm{Ca}_{3}\left(\mathrm{PO}_{4}\right)_{2}+\mathrm{Ca}(\mathrm{COO})_{2}+\mathrm{MgNH}_{4} \mathrm{PO}_{4}$

(5) $\mathrm{C}_{5} \mathrm{H}_{4} \mathrm{~N}_{4} \mathrm{O}_{3}$

これらの赤外線分光分析と $\mathrm{X}$ 線回析の実例を，それぞ れ図 1 および 2 に示した。

成分ごとの頻度は，燐酸カルシウムと落酸カルシウム との混合したもの (2)が最も多く，35個 (55\%), 粼酸カ ルシウムと粼酸マグネシウムアンモニウムとの混合した もの（3)12個 (19\%),これに蓚酸カルシウムを混じたも の (4) 9 個 (14\%), 蓚酸カルシウム (1) 4 個（6\%）な らびに尿酸（5）2 個（3\%）であつた。のこりの 4 個は 成分不明であつた。

2）結石の密度

30個の結石試料について密度を測定したが，操作中に 脆すぎて壊れたものが 7 個あり，実際に測定値の得られ たものは23個であつた（表 1).結石により輪層状構造を 
図 1
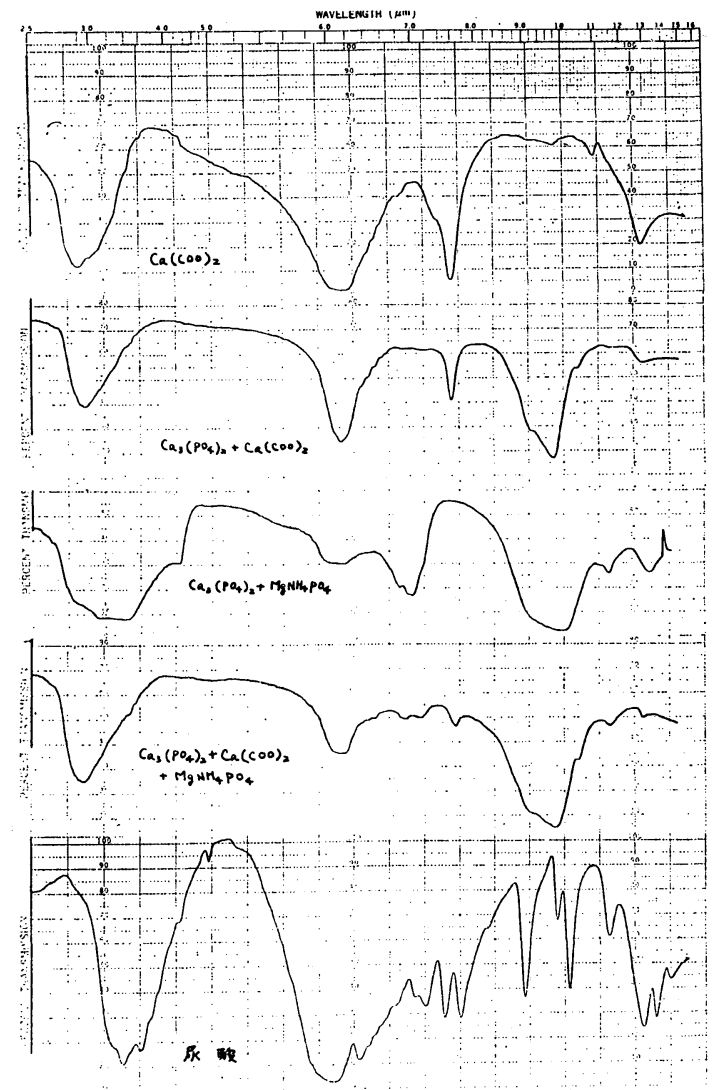

因 2

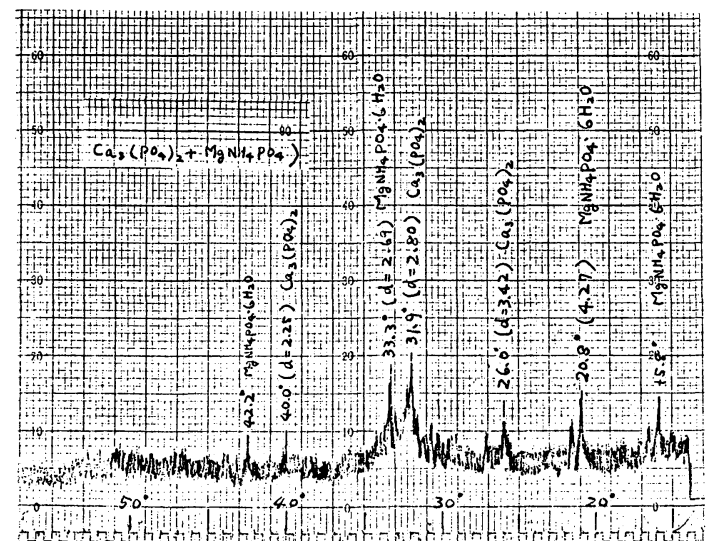

上

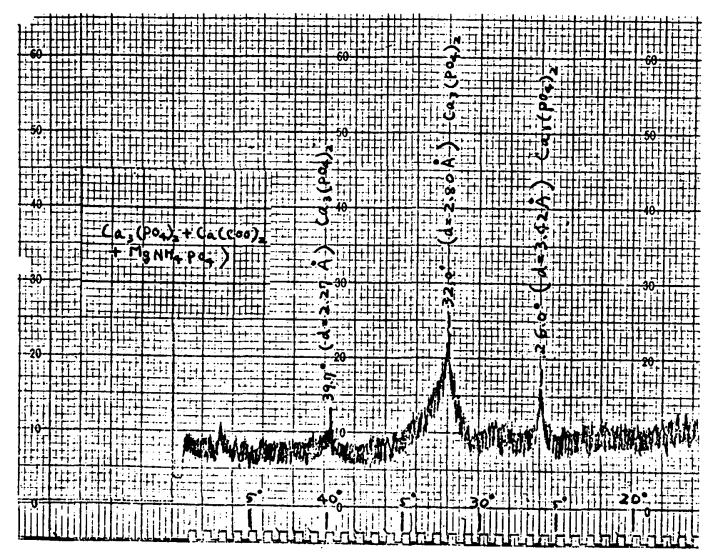

下

\begin{tabular}{|c|c|c|c|c|}
\hline No. & 成 & & 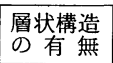 & \begin{tabular}{|l|} 
密 度 \\
$(\mathrm{g} / \mathrm{ml})$
\end{tabular} \\
\hline $\begin{array}{l}1 \\
2\end{array}$ & $\mathrm{Ca}(\mathrm{COO})_{2}$ & (1) & $\begin{array}{l}+ \\
-\end{array}$ & $\begin{array}{l}1.75 \\
1.05\end{array}$ \\
\hline $\begin{array}{r}3 \\
4 \\
5 \\
6 \\
7 \\
8 \\
9 \\
10 \\
11 \\
12 \\
13\end{array}$ & $\mathrm{Ca}_{3}\left(\mathrm{PO}_{4}\right)_{2}+\mathrm{Ca}(\mathrm{COO})_{2}$ & (2) & $\begin{array}{l}+ \\
+ \\
+ \\
+ \\
+ \\
- \\
- \\
- \\
- \\
- \\
-\end{array}$ & $\begin{array}{c}1.08 \\
1.10 \\
1.23 \\
1.28 \\
1.56 \\
+++ \\
1.41 \\
1.49 \\
1.59 \\
1.62 \\
1.72\end{array}$ \\
\hline $\begin{array}{l}14 \\
15 \\
16 \\
17 \\
18 \\
19 \\
20 \\
21\end{array}$ & $\mathrm{Ca}_{3}\left(\mathrm{PO}_{4}\right)_{2}+\mathrm{MgNH}_{4} \mathrm{PO}_{4}$ & (3) & $\begin{array}{l}+ \\
+ \\
+ \\
+ \\
+ \\
+ \\
+ \\
+\end{array}$ & $\begin{array}{c}+++ \\
+++ \\
1.04 \\
1.10 \\
1.30 \\
1.36 \\
1.38 \\
1.38\end{array}$ \\
\hline $\begin{array}{l}22 \\
23 \\
24 \\
25 \\
26 \\
27 \\
\end{array}$ & $\begin{array}{l}\mathrm{Ca}_{3}\left(\mathrm{PO}_{4}\right)_{2}+\mathrm{Ca}(\mathrm{COO})_{2} \\
\quad+\mathrm{MgNH}_{4} \mathrm{PO}_{4}\end{array}$ & (4) & $\begin{array}{l}+ \\
+ \\
+ \\
+ \\
+ \\
+\end{array}$ & $\begin{array}{c}+++ \\
+++ \\
+++ \\
+++ \\
0.97 \\
1.41\end{array}$ \\
\hline 28 & $\mathrm{C}_{5} \mathrm{H}_{4} \mathrm{~N}_{4} \mathrm{O}_{3}$ & $(5)$ & + & 1.46 \\
\hline $\begin{array}{l}29 \\
30\end{array}$ & 不 明 & (u) & + & $\begin{array}{l}1.33 \\
1.13\end{array}$ \\
\hline
\end{tabular}

十+十成形中に脆すぎててわれてしまつたもの 
図 3
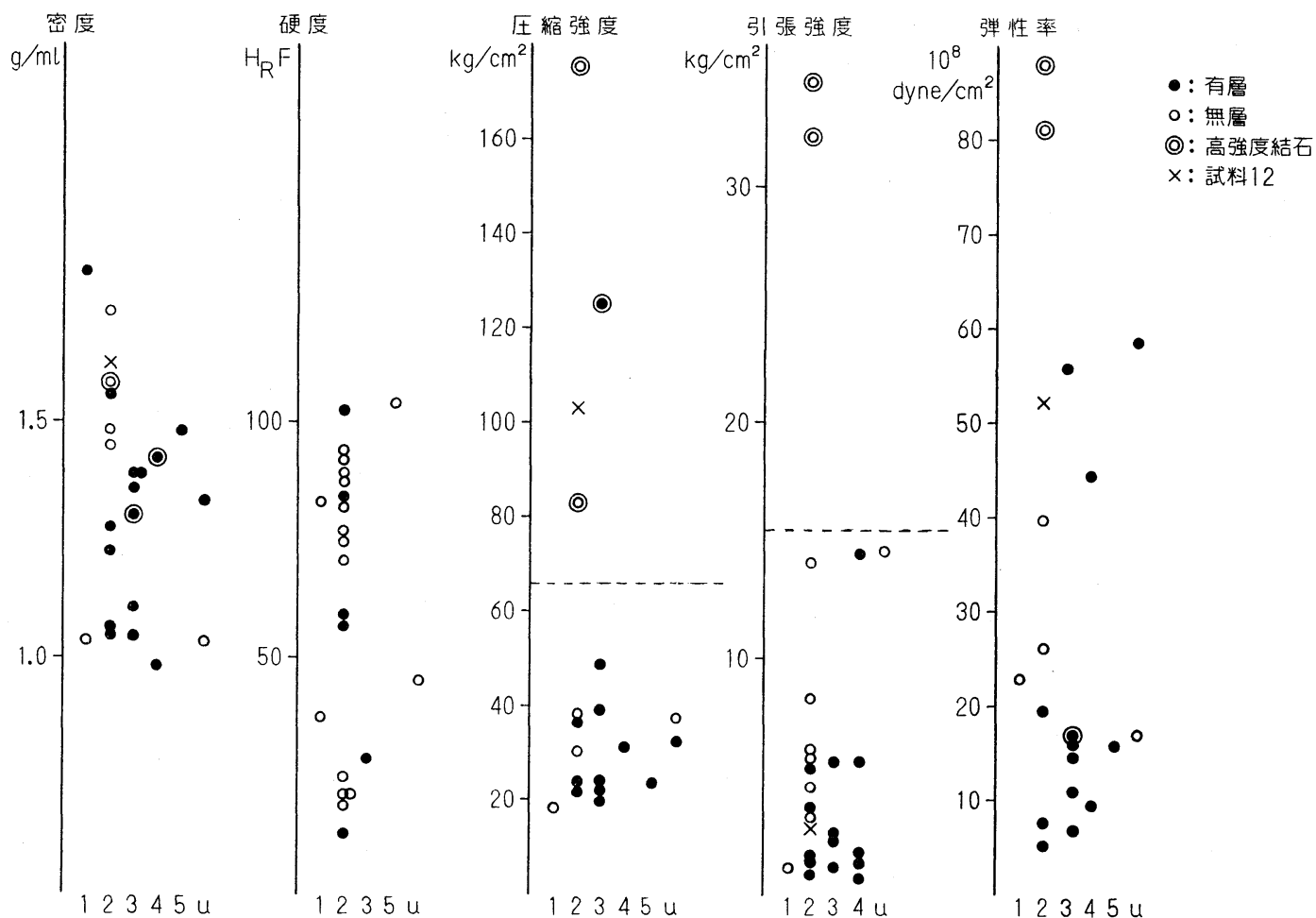

@: 高強度結石

$x:$ 試料 12

呈するものと呈さないものがあるので，その有無をる併 記した。

密度は0.97 1.75g/ml の範囲に一様に分布し, 全試 料の平均值は $1.34 \mathrm{~g} / \mathrm{ml}$ であつた (四 3 ). 各成分ごとの 密度には，それほど有意差はみられなかつたが，燐酸カ ルシウムと蓚酸カルシウムの混合結石 (2)で, 輪層状構 造の有無により密度を比較してみると, 輪層状構造のあ るものでは平均 $1.25 \mathrm{~g} / \mathrm{ml}$, 無いものでは $1.57 \mathrm{~g} / \mathrm{ml}$ とか なりの開きがみられた。また密度測定のため成形中脆す ぎて壊れた試料には，燐酸マグネシウムアンモニウムを 含有しているるの（3，4）が多かつた。尿酸結石（5） は例数が少なくはつきりしないが, 密度の高い方に属す ると考兄られた。

3）結石の硬度

硬度は29個の結石試料について調べた（表 2 ).同じく 輪層状構造の有無を併記した. 測定のための加工中, 軟 かすぎて壊れししまつたものが 7 個あり，とくに燐酸カ ルシウムと燐酸マグネシウムアンモニウムとの混合結石 （3）では 4 個中 3 個が壞れた。
硬度は12.5 102.5 $\mathrm{HR}_{\mathrm{R}} \mathrm{F}$ とかなりの幅に一様に分布 乙, 輪層状構造の有無や, 成分の違いに対して一定の傾 向はみられなかつた（図 3 ).尿酸結石は 1 例調べたのみ であつたが，かなりの硬度を有していた。測定が可能で あつた全試料の平均值は $60.9 \mathrm{HR}$ F であつた.

4）結石の圧縮強度, 引張り強度ならびに弾性率

これらの值は33個の結石試料に対して測定したが，圧 縮強度と引張り強度の両者について検索し得たのはこの らち14試料のみであつた。.その結果は, 輪層状構造の有 無も併記し, 表 3 亿示した。

a) 圧縮強度

王縮強度は19.2 $176.0 \mathrm{~kg} / \mathrm{cm}^{2}$ と広い範囲にわたつた が，測定した19試料中 15 試料 $(79 \%)$ は $65 \mathrm{~kg} / \mathrm{cm}^{2}$ 以下 の比較的狭、範围にまとまつて分布して括り, 残りの 4 試料 $(21 \%$ ，の印で示す）はそれ以上の広い範囲に分散 した（図 3 ). 全試料の平均值は $48.7 \mathrm{~kg} / \mathrm{cm}^{2}$ であつた。

燐酸カルシウムと萝酸カルシウムの混合結石 (2) 亿打 いては，輪層状構造の有無により圧縮強度に差があり， 有層のもの平均 $26.5 \pm 6.7 \mathrm{~kg} / \mathrm{cm}^{2}$, 無層のもの平均 $85.8 \pm$ 
表 2

\begin{tabular}{|c|c|c|c|c|}
\hline No. & 分 & & \begin{tabular}{|l|} 
層状構造 \\
の 有 無
\end{tabular} & $\begin{array}{l}\left.\text { 硬 }_{\left(\mathrm{H}_{\mathrm{R}}\right.} \mathrm{F}\right) \\
\end{array}$ \\
\hline $\begin{array}{l}38 \\
39\end{array}$ & $\mathrm{Ca}(\mathrm{COO})_{2}$ & (1) & - & $\begin{array}{l}81.8 \\
36.5\end{array}$ \\
\hline $\begin{array}{l}40 \\
41 \\
42 \\
43 \\
44 \\
45 \\
46 \\
47 \\
48 \\
49 \\
50 \\
51 \\
52 \\
53 \\
54 \\
55 \\
56 \\
57 \\
58 \\
59 \\
60\end{array}$ & $\mathrm{Ca}_{3}\left(\mathrm{PO}_{4}\right)_{2}+\mathrm{Ca}(\mathrm{COO})_{2}$ & (2) & $\begin{array}{l}+ \\
+ \\
+ \\
+ \\
+ \\
+ \\
+ \\
- \\
- \\
- \\
- \\
- \\
- \\
- \\
- \\
- \\
- \\
- \\
- \\
- \\
-\end{array}$ & $\begin{array}{c}+++ \\
+++ \\
12.5 \\
56.0 \\
58.0 \\
83.0 \\
102.0 \\
+++ \\
+++ \\
18.0 \\
20.0 \\
20.0 \\
23.0 \\
69.0 \\
73.5 \\
76.0 \\
82.0 \\
85.5 \\
88.0 \\
91.0 \\
92.5\end{array}$ \\
\hline $\begin{array}{l}61 \\
62 \\
63 \\
64 \\
\end{array}$ & $\mathrm{Ca}_{3}\left(\mathrm{PO}_{4}\right)+\mathrm{MgNH}_{4} \mathrm{PO}_{4}$ & (3) & $\begin{array}{l}+ \\
+ \\
- \\
+\end{array}$ & $\begin{array}{c}+++ \\
+++ \\
+++ \\
28.5\end{array}$ \\
\hline 65 & $\mathrm{C}_{5} \mathrm{H}_{4} \mathrm{~N}_{4} \mathrm{O}_{3}$ & $(5)$ & - & 102.5 \\
\hline 66 & 不 & $(\mathrm{u})$ & + & 40.0 \\
\hline
\end{tabular}

十+十成形中に脆すぎててわれてしまつたもの

$52.7 \mathrm{~kg} / \mathrm{cm}^{2}$ と, 無層の結石に強いものが多くみられ た．成分による差はあまり明らかではなかつたが，燐酸 カルシウム, 蓚酸カルシウム括よび燐酸マグネシウムア ソモニウムの 3 者混合の結石（4)は，脆くて試料作製の 段階で壊れるものが多かつた。

b ) 引張り強度

引張り強度も, $0.8 \sim 34.3 \mathrm{~kg} / \mathrm{cm}^{2}$ と広い範囲にばらつ いたが，測定した25試料中 23 試料 (92\%) はやはり 15 $\mathrm{kg} / \mathrm{cm}^{2}$ 以下の比較的狭い範囲にまとまつて分布し, 残 りの 2 試料（ $8 \% ，$ ○印で示す）がこれらとかなりかけ 離れて高い值を示した（図 3 ）。この 2 試料は圧縮強度 でも高い值を示して括り，例外的に試料12（×印で示 す）のみが，圧縮強度が高いにもかかわらず引張り強度 は低かつた。全試料の平均值は $7.0 \mathrm{~kg} / \mathrm{cm}^{2}$ であつた。

ここでも輪層状構造を有する結石は弱く，無層の結石 は強い傾向にあり, 燐酸カルシウムと蓚酸カルシウムと の混合結石 (2)でみると, 有層のもの平均 $2.6 \pm 1.7 \mathrm{~kg} /$ $\mathrm{cm}^{2}$, 無層のもの平均 $12.4 \pm 11.5 \mathrm{~kg} / \mathrm{cm}^{2}$ と, かなりの差
がみられた，成分による差はやはりあまり明らかではな かつた。

圧縮強度と引張り強度の両者について検索し得た14試 料について, 両強度の間の関係をみると, 図 4 のごと く, 試料12の例外（×印で示す）を除くとほぼ比例関係 が成立し，圧縮強度を $\mathrm{y}$ ，引張り強度を $\mathrm{x}$ とするとそ の関係式は下のごとくであつた。

$$
\mathrm{y}=3.34 \mathrm{x}+15.8 \quad(\mathrm{r}=0.890)
$$

\section{c) 弾性率}

弾性率は5.4〜 $88.0 \times 10^{8} \mathrm{dyne} / \mathrm{cm}^{2}$ の範囲にあつた が，その分布は比較的一様であつた（図 3 ）. 圧縮強度・

図 4

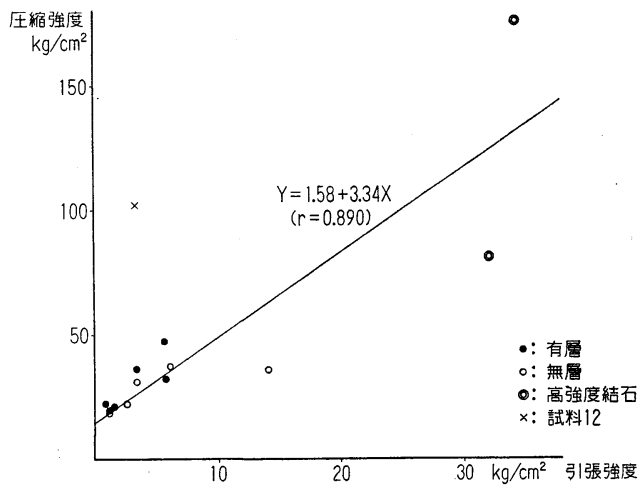

図 5

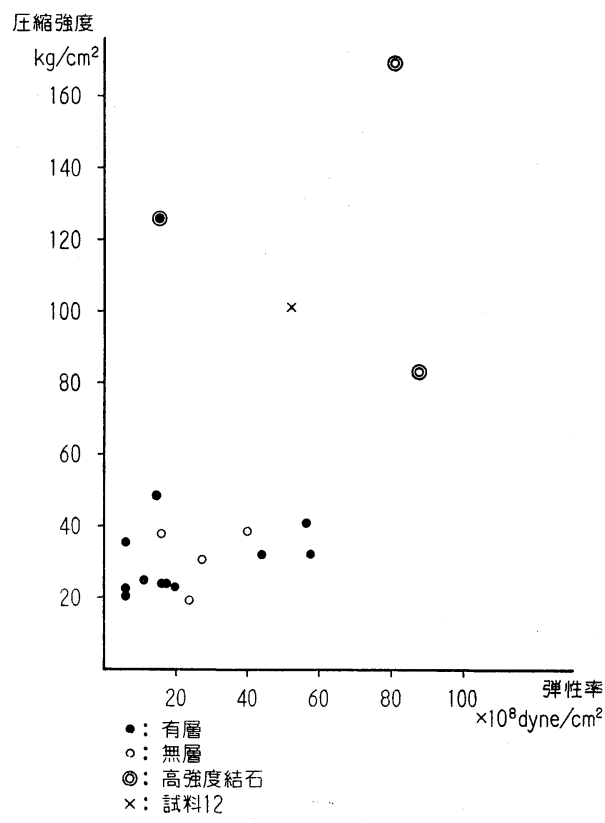


表 3

\begin{tabular}{|c|c|c|c|c|c|c|}
\hline No. & 分 & & $\begin{array}{l}\text { 層状構造 } \\
\text { 無 }\end{array}$ & $\begin{array}{l}\text { 氐縮強度 } \\
\left(\mathrm{kg} / \mathrm{cm}^{2}\right)\end{array}$ & $\begin{array}{l}\text { 引張強度 } \\
\left(\mathrm{kg} / \mathrm{cm}^{2}\right)\end{array}$ & 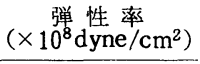 \\
\hline 2 & $\mathrm{Ca}(\mathrm{COO})_{2}$ & (1) & - & 19.2 & 1.0 & 22.5 \\
\hline 3 & \multirow[t]{13}{*}{$\mathrm{Ca}_{3}\left(\mathrm{PO}_{4}\right)_{2}+\mathrm{Ca}(\mathrm{COO})_{2}$} & \multirow[t]{13}{*}{ (2) } & $\begin{array}{l}+ \\
+\end{array}$ & 21.4 & 1.3 & 19.3 \\
\hline $\begin{array}{l}4 \\
5\end{array}$ & & & $\begin{array}{l}+ \\
+\end{array}$ & 35.9 & 5.3 & 5.4 \\
\hline 6 & & & + & \multirow[t]{2}{*}{22.2} & 0.8 & \multirow[t]{2}{*}{7.3} \\
\hline 8 & & & - & & 4.6 & \\
\hline 9 & & & - & \multirow[t]{2}{*}{37.3} & 6.0 & \multirow[t]{2}{*}{39.6} \\
\hline 10 & & & - & & 5.8 & \\
\hline 11 & & & - & 176.0 & 34.3 & 81.7 \\
\hline 12 & & & - & \multirow[t]{2}{*}{102.8} & 3.3 & \multirow[t]{2}{*}{52.1} \\
\hline 13 & & & - & & 14.0 & \\
\hline 27 & & & - & \multirow[t]{3}{*}{82.7} & 32.0 & \multirow[t]{3}{*}{88.0} \\
\hline 32 & & & + & & 3.8 & \\
\hline 33 & & & - & & 8.2 & \\
\hline 34 & & & - & 30.1 & 3.3 & 25.6 \\
\hline 14 & \multirow{7}{*}{\multicolumn{2}{|c|}{$\mathrm{Ca}_{3}\left(\mathrm{PO}_{4}\right)_{2}+\mathrm{MgNH}_{4} \mathrm{PO}_{4}$}} & + & & 2.3 & \\
\hline 16 & & & + & 22.7 & & 15.5 \\
\hline 17 & & & + & 19.6 & 1.1 & 7.1 \\
\hline 18 & & & + & 125.0 & & 15.9 \\
\hline 19 & & & + & 22.6 & 2.5 & 10.6 \\
\hline 20 & & & + & 47.2 & 5.5 & 14.9 \\
\hline 21 & & & + & 39.2 & & 55.8 \\
\hline 22 & \multirow{8}{*}{\multicolumn{2}{|c|}{$\begin{array}{l}\mathrm{Ca}_{3}\left(\mathrm{PO}_{4}\right)_{2}+\mathrm{Ca}(\mathrm{COO})_{2} \\
\quad+\mathrm{MgNH}_{4} \mathrm{PO}_{4}\end{array}$}} & + & & 0.8 & \multirow{8}{*}{$\begin{array}{c}9.4 \\
44.2 \\
+++ \\
+++\end{array}$} \\
\hline 23 & & & + & & 1.3 & \\
\hline 24 & & & + & +++ & 1.4 & \\
\hline 25 & & & + & & 14.2 & \\
\hline 26 & & & + & +++ & & \\
\hline 31 & & & + & 32.0 & 5.7 & \\
\hline 35 & & & + & +++ & & \\
\hline 36 & & & + & +++ & & \\
\hline 28 & $\mathrm{C}_{5} \mathrm{H}_{4} \mathrm{~N}_{4} \mathrm{O}_{3}$ & (5) & + & 22.7 & & 15.5 \\
\hline 30 & \multirow[t]{2}{*}{ 不 明 } & \multirow[t]{2}{*}{ (u) } & - & 36.6 & \multirow[t]{2}{*}{14.2} & 16.4 \\
\hline 37 & & & + & 30.7 & & 58.4 \\
\hline
\end{tabular}

十+十成形中に脆すぎててわれてしまつたあの

引張り強度の高かつた試料 (の印で示す) は概して弾 性率も高い値を示したものの，例外（試料18）もあり， また強度が低くても弾性率の高い試料もみられた，測定 した 20 試料の平均值は $30.3 \times 10^{8} \mathrm{dyne} / \mathrm{cm}^{2}$ であつた。

弾性率についても同様，成分による差よりも輪層状構 造の有無による差の方が目についた．燐酸カルシウムと 苳酸カルシウムの混合結石 (2)では, 有層のもの平均

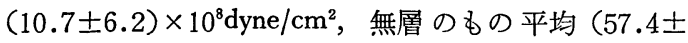
$24.0) \times 10^{8} \mathrm{dyne} / \mathrm{cm}^{2}$ と, 明らかな差がみられた。

同一の試料について圧縮強度と弾性率との関係をみる と，図５のごとく，あまり明らかな比例関係はなく，強 度の高い試料も低い試料も，弾性率についてかなり広い 範囲に分布することがわかつた。

\section{考按}

尿路結石を破碎する目的には，古くから行われてきた 器械的方法のほか飞, 強力超音波を用いる方法 (Coats $\left.{ }^{2}\right)$ 1956)，レーザーを用いる方法 (Bush ${ }^{3)}$ 1966), 電気水圧 効果を利用する方法 (YPAT-14)，Montreal World Fair 1967）などがあり，このうち強力超音波 ${ }^{5)}$ と YPAT-16) については，本邦でも実際に応用した報告がある。しか しながら，いずれす治験程度の論文にすぎず，結石破砕 の基本に立ち帰つて結石の強度から検索をはじめたもの はない。

その点私たちが開発しよらとしている微小発破は，ま つたく未知の領域に属する技術であるので，これを結石 破砕に応用するためには，どらしても結石の成分を分析 
し,ささらにその強度を調べた上で, 破砕実験のための結 石モデルを作製する必要があつた.

まず尿路結石の分析のために，私たちは本邦では，市 川, 高崎 ${ }^{7)}$ につて確立された赤外線分光分析を主に, 補助手段としてX線回析による分析と化学分析を併用し た. 私達の分析結果では, 高崎の500結石についての分 析結果 ${ }^{8)}$ とその成分頻度が多少異なるように思えた。す なわち，一般にもつとも多いとされる燐酸カルシウムと 苳酸カルシウムの混合結石（2）については，高崎の報告 に抢ける50.8\%という数字と注济頻度が一致したが，高 崎が $17.4 \%$ で第 2 位に挙げている葆酸カルシウム単独結 石（1）の頻度は低かつた．また高崎が $3.2 \%$ で第 5 位に 挙げている燐酸カルシウム単独結石は私たちの試料中に は見当らず，逆に高崎がそれぞれ第 3 位 $(16.4 \%)$ 特よ び第 4 位 (5.6\%) としている燐酸マグネシウムアンモ二 ウム結石掞よびこれに落酸カルシウムを混じた結石は， 私達の試料では常に燐酸カルシウムを混じていた。

しかし微量の燐酸カルシウムは種々の成分の結石中に 共通して広く含まれているし，また橉酸マグネシウムア ソモニウムは単独では結石をつくらず，常に燐酸カルシ ウムや炭酸カルシウムを゙混じた結石を作るとされてい る の結果とは大差がないことになる。

つぎに結石の物理的性質に関して，その密度・硬度・ 圧縮強度・引張り強度・弾性率の 5 項目を, 結石の組成 および輪層状構造の有無と関連させながら検索した。

密度の測定を行つた30個のらち，7個の結石は試料成 形中に脆すぎて壊れてしまつたが，このうち 6 個はその 成分に燐酸マグネシウムアンモニウムを含んでいた，高 崎8) もこの燐酸マグネシウムアンモニウム結石は，大多 数は脆くて破壊し易く, 割面はしばしば輪層状構造を有 すると述べているが，私たちが得た所見るこれと同様で あつた。頻度の高かつた燐酸カルシウムと葆酸カルシウ ムとの混合結石（2）の中では, 輪層状構造の有無により その密度に差があつた. 今回測定の全試料の密度分布は $0.97 \sim 1.75 \mathrm{~g} / \mathrm{ml}$ で, 平均 $1.34 \mathrm{~g} / \mathrm{ml}$ となり, 建築用レン ガの生焼きのもの $1.6 \mathrm{~g} / \mathrm{ml}^{9)}$ に近いといえる。

硬度の測定には種々の方法があり，その定義も一定で はないが，私たちは最も一般的な Rockwell 硬度計を用 いた、実際に硬度を測定したものは29試料であつたが， そのうち燐酸カルシウムと苳酸カルシウムの混合結石 (2)が21試料と大部分を占め，成分の上からはやや試料 の選び方が偏つていたかも知れない。しかしそれでも硬
度の分布は12.5 102.0 $\mathrm{H}_{\mathrm{R}} \mathrm{F}$ とかなりの幅がみられた。 全試料の平均値は $60.9 \mathrm{HRF}$ で, これは人の上腕骨の 硬度 $61 \sim 66 \mathrm{H}_{\mathrm{R}} \mathrm{F}^{10)}$ に添注一致する。

圧縮強度はやはり広く分散していたが，ほ淁 $65 \mathrm{~kg} / \mathrm{cm}^{2}$ を境にして，全体を大きく 2 群に分けることが可能なよ らに思われた。輪層状構造を有している結石の圧縮強度 は弱い傾向があつたが，燐酸カルシウムと蓚酸カルシウ ムとの混合結石（2)に打いて，それはとくに顕著であつ た.

全試料の平均值は $48.7 \mathrm{~kg} / \mathrm{cm}^{2}$ であつたが，通常の石 材にはこれ活ど強度の弱いものはなく,燐酸カルシウム と苳酸カルシウムの混合結石 (2)の無層のものの平均圧 縮強度值 $85.8 \mathrm{~kg} / \mathrm{cm}^{2}$ が, 石材中ではもつとも強度の弱 い部類に属する凝灰岩大谷白石の压縮強度 $86.0 \mathrm{~kg} / \mathrm{cm}^{2}{ }^{9}$ ) に近い值を示している.

引張り強度もやはりばらつきが大きいが, 压縮強度 と同様注湆 $15 \mathrm{~kg} / \mathrm{cm}^{2}$ を境にして全体を 2 群に分類でき た。燐酸カルシウムと蓚酸カルシウムとの混合結石のう ち輪層状構造のあるものは平均 $2.6 \mathrm{~kg} / \mathrm{cm}^{2}$, 無構造のも のは平均 $12.4 \mathrm{~kg} / \mathrm{cm}^{2}$ となり, 他の物質と比較すると, 前者はヒ卜膀胱壁の引張り強度 $2.5 \mathrm{~kg} / \mathrm{cm}^{2}{ }^{11)}$, 後者は凝 灰岩大谷白石の引張り強度 $9.0 \mathrm{~kg} / \mathrm{cm}^{2}{ }^{2)}$ 飞近いことがわ かる.

さて以上の結果をまとめてみると，尿路結石の力に対 する物理的諸性質は，その成分とはあまり関係がないよ うに思われる。燐酸マグネシウムアンモニウムを含有す る結石はたしかに脆いが，中には試料49のように非常に 高い強度を示すものもあり，普遍的な性質とはいいきれ なかつたそそれに比べると結石の輪層状構造の有無は明 らかに強度と関係があり，もちろん前述の試料18のよう な例外はあるものの，一般的に有層の結石は無層のもの に比べて, 強度が低く, ことに引張りに弱い傾向がみら れた．ただし硬度についてはこのような傾向がみられな いので, 有層の結石がこわれやすいのはやはり構造上の 問題であつて，結石を構成する物質そのものの硬さの問 題ではないと推察できる。

全試料を通じて圧縮強度と引張り強度とはかなりよく 相関した。唯一の例外は試料12であつたが，この試料は 引張り強度試験に供する前にすでにヒビが入つていた可 能性も考兄られる. 両者の関係式は前述のごとく，

$$
\mathrm{y}=3.34 \mathrm{x}+15.8 \quad(\mathrm{r}=0.890)
$$

であつたが，試みに各種の石材について青木の資料きに もとずき同様に両者の関係を概算すると， 


$$
y=16.3 x+304 \quad(r=0.750)
$$

となり, その勾配は結石の場合に比べてかなり急であ る.すなわち尿路結石は, 通常の石に比べて圧縮に弱く 引張りに強い性格をもつているということができる.

これに対し, 結石の強度と弾性率の間にはそれほどは つきりした比例関係は認められず, 強度の低い結石でも かなり大さい弾性率を示す場合があつた. 結石の強度と 硬度との関係については, 両者を同一の試料で測定する ことができなかつたので, 今回は明らかにし得なかつ た。

結石の密度や硬度はある範囲に一様に分布していたの に比べ, 王縮強度と引張り強度は, 大部分の試料が比較 的低い值の狭い範囲にまとまつて分布し, 残りの少数の 試料のみが高い値の広い範囲に分散して, 両者の間にあ る空白の領域がみられたことは, かなり重要な所見であ る.なぜなら, 全試料の平均をとると, その值は空白の 領域に落ちてしまい, 統計的にあまり意味がなくなつて しまうからである.したがつて結石の強度については, これを前述の空白の領域を境に 2 種に分けて考えるの が，より妥当であると思われる.

私たちの成績によれば，この境界値はほぼ圧縮強度 65 $\mathrm{kg} / \mathrm{cm}^{2}$, 引張り強度 $15 \mathrm{~kg} / \mathrm{cm}^{2}$ のあたりにあると思われ た. 前述のごとく結石の圧縮強度と引張り強度の間には 比例関係があり, その関係式に扣いて引張り強度 $15 \mathrm{~kg} /$ $\mathrm{cm}^{2}$ に相当する圧縮強度は $65.9 \mathrm{~kg} / \mathrm{cm}^{2}$ なので, その意 味でもこの境界值は妥当なところであろう。

この結果, 尿路結石は圧縮強度 $65 \mathrm{~kg} / \mathrm{cm}^{2}$, 引張り強度 $15 \mathrm{~kg} / \mathrm{cm}^{2}$ を境に, これより強度の高い結石と強度の低 い結石との 2 種に分類できることになつた。 そこで私た ちは前者を高強度結石, 後者を低強度結石と命名した. 高強度結石は結石全体の10２0\%にすぎず，輪層状構 造をもたないことが多いが，例外もある，その強度は， 大体土木材料として用いられる石材としてはもつとも強 度の低い凝灰岩（大谷石, 沢田石など）に相当する程度 と考えてよく, 石材の分類では軟石ないし準堅石の範疇 にある

低強度結石は結石全体のほぼ80 90\%を占め, 輪層状 構造はあるものもないものもあるが, 輪層状構造を有す るものは中でも概して強度が低い，その強度は通常の石 材よりかなり低く, 引張り強度でいえば膀胱壁などの生 体軟部組織のそれに近い.すなわち強度についてのみみ れば，自然界でいらいわゆる「石」の概念にはあたらな いものである。
このよらに強度の上から結石を 2 種に分類すること は, 結石破砕の面からみても非常に好都合である.なぜ なら大多数の結石は低強度結石なのであるから, 一応結 石破砕のためのエネルギーとしては，第 1 段階として前 述の境界值程度の強度の結石を破砕できる量を用意し， これで破砕できないときには第 2 段階として, 高強度結 石用のさらに多くのエネルギーを与えることにすればよ いからである.これによつて大多数の結石は, 必要最小 限のエネルギーによつて破砕できることになる．

そこで本研究の目的である破砕実験のための結石モデ ルとしては，それぞれの範囲内で考えられる最高強度值 を設定值として,つぎの 2 種類の強度のものを作製する ことが望ましい。

1）低強度結石モデル：王縮強度 $65 \mathrm{~kg} / \mathrm{cm}^{2}$ 前後, 引 張り強度 $15 \mathrm{~kg} / \mathrm{cm}^{2}$ 前後.

2）高強度結石モデル：圧縮強度 $180 \mathrm{~kg} / \mathrm{cm}^{2}$ 前後, 引 張り強度 $35 \mathrm{~kg} / \mathrm{cm}^{2}$ 前後.

破砕実験のための結石モデルとしては, 硬度や弾性率 の設定は第 2 義的であると考学られるが, 一応硬度 は $100 \mathrm{H}_{\mathrm{R}} \mathrm{F}$, 弾性率は低強度結石モデルで50 $60 \times 10^{8} \mathrm{dyne} /$ $\mathrm{cm}^{2}$, 高強度結石モデルで $80 \sim 90 \times 10^{8} \mathrm{dyne} / \mathrm{cm}^{2}$ 前後を目 安にすれば, 充分であると思われる.

ただしここで注意しなければならないのは，今回測定 した試料は，いずれる人体から採取されたのち長時間に わたつて充分に乾燥された試料であつたことである.こ れらの結石が尿路中に尿に浸されて存在した時の物理的 諸性質は, 当然乾燥後のそれとは異なることが予想され る.私たちは現在次の段階として，人体から採取した直 後の結石試料の測定を行つているが, その結果でも, 強 度, ことに王縮強度に多少のずれがみられるように思わ れる。

また尿路結石の特徵として，その成分には結晶部分以 外にかなりの有機成分が含まれ，それがいわば糊のよう に結晶同志を結びつけている可能性がある.今回明らか になつた，尿路結石の圧縮強度と引張り強度との関係は 自然界の石とはやや趣きを異にするといら事実にも，お そらくこのような有機成分の作用が関連しているのでは ないかと推測され，現在私たらはこの面に関しても検索 を続けている。

したがつて最終的に決定される結石モデルの設定值に は，まだ多少の変更があり得ることを断りして，この 稿を閉じることにする。

結 論 
微小発破による尿路結石破砕計画の一環として, 破砕 実験に用いる結石モデルの作製を目的に，乾燥結石試料 66個について, その組成, 密度 硬度, 圧縮強度, 引張 り強度ならびに圧縮弾性率を測定した。結果は次のごと くであつた。

1）結石の成分については, 従来の報告と大差はなか つた.

2）結石の密度は $0.97 \mathrm{~g} / \mathrm{ml}$ から $1.75 \mathrm{~g} / \mathrm{ml}$ であつた.

3）結石の硬度は $12.5 \mathrm{H}_{\mathrm{R}} \mathrm{F}$ から $102.5 \mathrm{HR}_{\mathrm{R}}$ であつた。

4）結石の圧縮強度は $19.2 \mathrm{~kg} / \mathrm{cm}^{2}$ から $176.0 \mathrm{~kg} / \mathrm{cm}^{2}$ で あつた。

5）結石の引張り強度は0.8 $\mathrm{kg} / \mathrm{cm}^{2}$ か $534.3 \mathrm{~kg} / \mathrm{cm}^{2}$ であつた。

6）結石の圧縮強度と引張り強度の間には一定の比例 関係が認められた。

7) 弾性率は5.4 $\times 10^{8} \mathrm{dyne} / \mathrm{cm}^{2}$ か $588.0 \times 10^{8}$ dyne/ $\mathrm{cm}^{2}$ であつた。

8）結石の成分はその強度とあまり関係がないが，結 石が構造的に輪層状構造を有するか否かは，その強度と かなりの関係を有するように思われた．

9）すべての尿路結石は，その強度上，乾燥状態に特 ける压縮強度 $65 \mathrm{~kg} / \mathrm{cm}^{2}$, 引張 り強度 $15 \mathrm{~kg} / \mathrm{cm}^{2}$ を境界值 として, 全体の 80 ～90\%を占める低強度結石と, 全体の 10〜20\%を占める高強度結石とに分類されらることが判
明した。

10）乾燥状態に扣ける結石の強度測定結果よりみれ ば，尿路結石破砕実験に用いるための結石モデルとして は，王縮強度 $65 \mathrm{~kg} / \mathrm{cm}^{2}$, 引張り強度 $15 \mathrm{~kg} / \mathrm{cm}^{2}$ 前後の低 強度結石モデルと, 同じく圧縮強度 $180 \mathrm{~kg} / \mathrm{cm}^{2}$, 引張り 強度 $35 \mathrm{~kg} / \mathrm{cm}^{2}$ 前後の高強度結石モデルの, 2 種 が必要 であると思われた。

\section{文献}

1) 渡辺 泱, 生沼仙三 : 日泌尿会誌, 68, 243, 1977.

2) Coats, E.C.: J. Urol., 75, 865, 1956.

3) Bush, I.M. et al.: 61st Annual Meeting, American Urological Association, 1966.

4) Apparat "YPAT-1". V/O Medexport, USSR, Moscow.

5) Terhorst, T. and 八竹 直: 泌尿紀要, 20, $533,1974$.

6) 高崎悦司, 島野栄一郎, 永田正義: 臨床泌尿器 科，29，571，1975。

7) 市川篤二, 柿崎勉, 今村一男, 高崎悦司, 千原 吳郎：日泌尿会誌，50，1，1959.

8) 高崎悦司：治療，52，1657，1970.

9) 青木楠男：土木材料，才一么社， 1976.

10）杉山吉克：京府医大誌； 68，557，1960.

11 ）浅見郁夫：京府医大誌，70，767，1961. （1976年10月30日受付，特別掲載） 